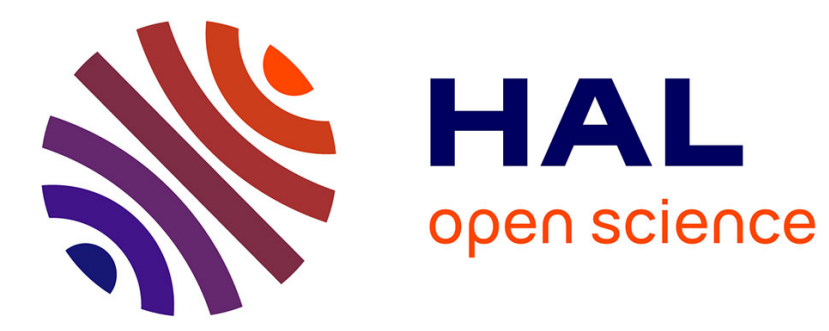

\title{
Electrocatalytic studies on imidazolium based ionic liquids: defining experimental conditions
}

\author{
Miguel A. Montiel, José Solla-Gullon, Vicente Montiel, Carlos M \\ Sánchez-Sánchez
}

\section{To cite this version:}

Miguel A. Montiel, José Solla-Gullon, Vicente Montiel, Carlos M Sánchez-Sánchez. Electrocatalytic studies on imidazolium based ionic liquids: defining experimental conditions. Physical Chemistry Chemical Physics, 2018, 20 (28), pp.19160 - 19167. 10.1039/c8cp02662a . hal-01877660

\section{HAL Id: hal-01877660 \\ https://hal.sorbonne-universite.fr/hal-01877660}

Submitted on 21 Sep 2018

HAL is a multi-disciplinary open access archive for the deposit and dissemination of scientific research documents, whether they are published or not. The documents may come from teaching and research institutions in France or abroad, or from public or private research centers.
L'archive ouverte pluridisciplinaire HAL, est destinée au dépôt et à la diffusion de documents scientifiques de niveau recherche, publiés ou non, émanant des établissements d'enseignement et de recherche français ou étrangers, des laboratoires publics ou privés. 


\title{
Electrocatalytic studies on imidazolium based ionic liquids: defining experimental conditions.
}

\author{
Miguel A. Montiel, a José Solla-Gullón ${ }^{a}$, Vicente Montiel ${ }^{\mathrm{a}}$ and Carlos M. Sánchez-Sánchez ${ }^{* b}$
}

a. Instituto Universitario de Electroquímica, Universidad de Alicante, Ap. 99, 03080 Alicante, Spain.

b. Sorbonne Université, CNRS, Laboratoire Interfaces et Systèmes Electrochimiques, LISE, F-75005, Paris, France.

*carlos.sanchez@upmc.fr; Tel: +33144274158

The number of publications devoted to study electrochemical reactions in room temperature ionic liquids (RTILS) is constantly growing, but very few of them have been devoted to define proper experimental conditions to obtain reproducible electrochemical results. In this work, we demonstrate that the combination of a proper RTIL purification treatment and a filtered Ar gas stream allow to obtain featureless voltammograms in $\left[\mathrm{C}_{4} \mathrm{mim}\right]\left[\mathrm{BF}_{4}\right],\left[\mathrm{C}_{4} \mathrm{mim}\right]\left[\mathrm{NTf} \mathrm{f}_{2}\right]$, and $\left[\mathrm{C}_{4} \mathrm{~m}_{2} \mathrm{im}\right]\left[\mathrm{NTf}_{2}\right]$, which otherwise present signals associated to different types of impurities such as water and some minor electroactive impurities acquired during the RTILs synthesis process. Moreover, we demonstrate that bubbling $\mathrm{Ar}$, or other inert gas, through the electrolyte in order to purge $\mathrm{O}_{2}$ dissolved in RTILs is one of the major sources of water and $\mathrm{O}_{2}$ impurities incorporated at RTILs within the electrochemical cell. To overcome this source of water income, we have incorporated a gas stream purification filter before the gas reaches the RTIL in the electrochemical cell. To illustrate the effect of these impurities in relevant electrocatalytic studies, we study the electrocatalytic reduction of $\mathrm{CO}_{2}$ on Pt nanoparticles and the key role of an appropiate filter when the $\mathrm{CO}_{2}$ gas stream is bubbled within imidazolium based RTILs. Our cyclic voltammetric studies point out that $\mathrm{CO}_{2}$ electroreduction on Pt nanoparticles only presents activity in $\left[\mathrm{C}_{4} \mathrm{mim}\right]\left[\mathrm{NTf}_{2}\right]$ and $\left[\mathrm{C}_{4} \mathrm{~m}_{2} \mathrm{im}\right]\left[\mathrm{NTf}_{2}\right]$, thus suggesting that $\mathrm{C}-2$ position at the imidazolium ring is not the key position in $\mathrm{CO}_{2}$ electrochemical reduction. In contrast, the same $\mathrm{Pt}$ nanoparticles are inactive towards $\mathrm{CO}_{2}$ electroreduction in $\left[\mathrm{C}_{4} \mathrm{mim}\right]\left[\mathrm{BF}_{4}\right]$, which is a more hydrophilic RTIL. 


\section{Introduction}

Room temperature ionic liquids (RTILs) or low temperature molten salts [1] have emerged as promising media to improve performance in electrochemical applications and devices. In particular, RTILs provide new interesting results in electrochemical sensors [2,3], electrosynthesis of organic compounds via alternative routes [4] and synthesis of functional materials with imidazolium-based RTILs for various and relevant applications [5-8]. In addition to this, the use of RTILs in the field of energy conversion and storage is a promising field, for instance, in redox flow batteries [9], supercapacitors [10] and electrocatalytic reactions such as oxygen reduction reaction [11], CO electrooxidation [12-13] and $\mathrm{CO}_{2}$ electroreduction [14-18], among others. The increasing interest on this topic, which leads to thousands of publications per year, is not only owe to the particular physicochemical properties of RTILs [19-20], but also due to the particular interactions of the RTIL with the electrode surface [21] and the interesting co-catalyst role played by imidazolium cations, particularly 1-alkyl-3-methylimidazolium cations $\left[\mathrm{C}_{n} \mathrm{mim}^{+}\right]$, in some reactions like $\mathrm{CO}_{2}$ electroreduction [22-24].

Experimental conditions for properly studying electrocatalytic reactions at nanoparticulated electrodes in aqueous media are well established in the literature [25-27]. Nevertheless, the relevant effect in RTILs electrochemical behavior of several experimental factors, which include temperature, water content and level of impurities [28-31] requires a strict control of those parameters. Usually, RTILs employed in electrocatalysis are chemically stable in the presence of air and moisture. However, they are not always pure and sometimes contain minor impurities acquired during the synthesis process such as $\mathrm{Li}^{+}, \mathrm{K}^{+}$or $\mathrm{Cl}^{-}$or sub-products of the previous synthesis of the precursors. For instance, if the selected cation is $\mathrm{C}_{4} \mathrm{mim}^{+}$, some methyl-imidazole or imidazole may be present. These impurities may cause coloration of the RTIL, can interfere with other reactants or even facilitate the decomposition of the RTIL. Consequently, some authors have proposed to eliminate them at the synthesis process [32]. Nevertheless, water absorbed remains as the most common impurity present in RTILs, since even hydrophobic RTILs absorb some. Thus, the presence of water and $\mathrm{O}_{2}$ within the RTILs provoke a relevant impact on the electrochemical response of most electrode materials, and particularly in Pt electrodes [31] due to its high catalytic activity. In spite of the fact that the number of publications devoted to study electrochemical reactions in RTILs is constantly growing, very few of them have been devoted to define proper experimental conditions, which should allow to obtain reproducible results. So far, only a few examples of RTIL purification treatments have been reported in the literature [28-30]. Those are mainly based either on RTILs vacuum-dried at moderate temperatures $\left(60-100^{\circ} \mathrm{C}\right.$ ) for $24-48 \mathrm{~h}$ or impurities sequestration by molecular sieves. In most cases, those purification treatments are carried out before entering the RTIL in the electrochemical cell. In fact, no attention has been paid to potential sources of impurities incorporated within the electrochemical cell. However, unless working within a globe-box [33], it is difficult to hold water and $\mathrm{O}_{2}$ contents significantly low all along the experiment. Interestingly, we have identified in this work the gas stream used to purge RTILs as one of the major sources of water and $\mathrm{O}_{2}$ impurities incorporated at RTILs within the electrochemical cell. For this reason, we propose to restrict those impurities, coming from either inert or reactive gas streams, by incorporating a commercially available gas filter at the gas inlet of the cell. Moreover, we highlight the misleading role of minor electroactive impurities present in RTILs, as well as we propose to quantify the water content in the RTIL at the beginning and at the end of each electrochemical experiment by Karl-Fisher titration as a control experiment. Herein we study by cyclic voltammetry the gas stream purification effect in both inert $(\mathrm{Ar})$ and reactive $\left(\mathrm{CO}_{2}\right)$ 
gases and the presence of minor electroactive impurities in RTILs using polycrystalline Pt and quasispherical $\mathrm{Pt}$ nanoparticles as electrode materials in three different ionic liquids, $\left[\mathrm{C}_{4} \mathrm{mim}\right]\left[\mathrm{BF}_{4}\right]$, $\left[\mathrm{C}_{4} \mathrm{mim}\right]\left[\mathrm{NTf}_{2}\right]$, and $\left[\mathrm{C}_{4} \mathrm{~m}_{2} \mathrm{im}\right]\left[\mathrm{NTf}_{2}\right]$. We demonstrate the effect of gas stream impurities is particularly relevant when an electrochemically reactive gas such as $\mathrm{CO}_{2}$ is involved in the reaction and strongly depends on the hydrophilicity of the RTIL.

\section{Experimental}

Chemicals. 1-Butyl-3-methylimidazolium tetrafluoroborate $\left[\mathrm{C}_{4} \mathrm{mim}\right]\left[\mathrm{BF}_{4}\right](>99 \%)$, 1-butyl-3methylimidazolium bis(trifluoromethanesulfonyl)imide $\left[\mathrm{C}_{4} \mathrm{mim}\right]\left[\mathrm{NTf}_{2}\right]$ (>99.5\%) and 1-butyl-2,3dimethyl-imidazolium bis(trifluoromethanesulfonyl)imide $\left[\mathrm{C}_{4} \mathrm{~m}_{2} \mathrm{im}\right]\left[\mathrm{NTf}_{2}\right]$ (>99\%) from lolitec, acetone $\left(\mathrm{CH}_{3} \mathrm{COCH}_{3}\right)$ from Fisher Scientific, ferrocene $\left(\mathrm{Fe}\left(\mathrm{C}_{5} \mathrm{H}_{5}\right)_{2}\right) 98 \%, \mathrm{H}_{2} \mathrm{PtCl}_{6} \cdot 6 \mathrm{H}_{2} \mathrm{O}$, polyethylene glycol dodecyl ether (BRIJ 30 ) and hydrazine monohydrate $\left(\mathrm{N}_{2} \mathrm{H}_{4} \bullet \mathrm{H}_{2} \mathrm{O}\right) 98 \%$ from Sigma-Aldrich and $\mathrm{n}$ heptane 99+\% from Across Organics. Two different gases were tested; Ar gas N50 (99.999\%, containing $<3 \mathrm{ppm} \mathrm{H}_{2} \mathrm{O}$ and $<2 \mathrm{ppm} \mathrm{O}_{2}$ ) $\mathrm{CO}_{2}$ gas $\mathrm{N} 48\left(99.998 \%\right.$ containing $<3$ ppm $\mathrm{H}_{2} \mathrm{O}$ and $<2 \mathrm{ppm} \mathrm{O}$ ). All gases were supplied by Air Liquide.

Polycrystalline Pt electrode and Pt nanoparticles synthesis. Single crystal Pt beads obtained by fusion and subsequent slow crystallization of a Pt wire $(99.95 \%, 0.5 \mathrm{~mm}$ in diameter) were used to prepare polycrystalline Pt electrodes. The experimental details for the water-in-oil (w/o) microemulsion synthesis and subsequent surface cleaning of the quasi-spherical Pt nanoparticles are detailed in previous contributions [25-26, 31].

Electrochemical measurements. The nanoparticulated Pt working electrodes were made by depositing a controlled volume $(5 \mu \mathrm{L})$ of a sonicated aqueous suspension containing the synthesized Pt nanoparticles $\left(0.0195 \mathrm{~cm}^{2} \mu \mathrm{L}^{-1}\right.$ ) on a glassy carbon (GC) disc (3 mm diameter, $0.071 \mathrm{~cm}^{2}$ geometric area). Pt polycrystalline electrodes were also used in some experiments. The electrochemical measurements were performed using a $\mathrm{CHI910B}$ or $\mathrm{CHI760E}$ bipotentiostat from $\mathrm{CH}$ Instruments. $\mathrm{Pt}$ wires were used as both counter and pseudoreference electrodes. All potentials have been referred to the ferrocenium/ferrocene $\left(\mathrm{Fc}^{+} / \mathrm{Fc}\right)$ potential scale, which is a well-accepted redox potential reference scale in RTILs [34]. All electrochemical measurements were done within a thermostatic jacketed electrochemical cell at $25 \stackrel{\circ}{ } \mathrm{C}$ to prevent temperature changes.

RTILs water content quantification. The water content in all RTILs studied here was quantified before and after each experiment by Karl-Fischer coulometric titration (C10SX from Mettler-Toledo). Measurement range $(10 \mu \mathrm{g}-200 \mathrm{mg})$. Titration RTIL samples of $3 \mathrm{~g}\left(\mathrm{H}_{2} \mathrm{O}\right.$ concentration detection limit $=4 \mathrm{ppm} / 0.3 \mathrm{mM})$.

RTILs purification treatments. In all cases, those treatments were carried out before entering the RTIL in the electrochemical cell. RTIL samples of $4 \mathrm{~mL}$ were treated in a $25 \mathrm{ml}$ glass balloon connected to a vacuum pump (model E2M2 from EDWARDS with an ultimate pressure of $1 \times 10^{-3}$ mbar). Purification treatments used: (A) conventional vacuum-temperature treatment. RTIL vacuumdried for $24 \mathrm{~h}$ at $80 . \mathrm{C}$ [35-39]; (B) vacuum-stirring treatment. RTIL vacuum-dried for $24 \mathrm{~h}$ at room temperature while stirring continuously at $800 \mathrm{rpm}$ [29]; (C) molecular sieve-based treatment. Firstly, RTIL vacuum-dried for $6 \mathrm{~h}$ stirring at room temperature and secondly vacuum-dried for $18 \mathrm{~h}$ (no stirring) at $60^{\circ} \mathrm{C}$ in the presence of molecular sieves $(0.3 \mathrm{~nm}$ pore size) $[28,30]$. 
Gas stream purification treatment. Either $\mathrm{Ar}$ or $\mathrm{CO}_{2}$ gas streams were used to purge RTILs within the electrochemical cell. Those gases were either directly bubbled into the RTIL solution or previously purified by passing them through a gas filter (model CP17973, Agilent) composed by $\mathrm{Al}_{2} \mathrm{O}_{3}$ $(50-75 \%), \mathrm{MnO}_{2}(\leq 10 \%), \mathrm{CuO}(\leq 10 \%)$, charcoal activated $(<10 \%), \mathrm{SiO}_{2}(\leq 3 \%)$ and $\mathrm{NiO}(<1 \%)$. This filter mainly removes $\mathrm{O}_{2}, \mathrm{H}_{2} \mathrm{O}$ and hydrocarbons traces from any gas stream and provides a gas outlet containing $<0.1 \mathrm{ppm} \mathrm{H}_{2} \mathrm{O}$ and $<50 \mathrm{ppb}_{2}$.

\section{Results and Discussion}

Table 1 summarizes the main results obtained when comparing all 3 different RTILs purification treatments pointing out that purification treatments $(B)$ and $(C)$ provide significantly lower final water contents than extensively used treatment $(A)$. Actually, water removal from $\left[\mathrm{C}_{4}\right.$ mim] $\left[\mathrm{BF}_{4}\right]$ using conventional vacuum-dried treatment at $80 \stackrel{\circ}{\circ}\left(62 \mathrm{ppm} \mathrm{H}_{2} \mathrm{O}\right.$, entry 1$)$ is clearly enhanced by the vacuum-stirring treatment at room temperature (entries 2 and 3), which reaches between 32 and 41 ppm $\mathrm{H}_{2} \mathrm{O}$ depending on the initial $\mathrm{H}_{2} \mathrm{O}$ concentration present in the RTIL. Moreover, treatment (A) requires a subsequent cooling step before performing the electrochemical experiments and this may induce water contamination, if the system is not well-isolated. One of the main limitations to effectively remove water from RTILs is their intrinsic low diffusion coefficient due to the high RTILs viscosity, which make them difficult to get dried quickly. Therefore, including stirring during the vacuum purification treatment contributes positively. Table 1 shows how purification treatment (B) applied to more hydrophobic and less viscous RTILs such as $\left[\mathrm{C}_{4} \mathrm{mim}\right]\left[\mathrm{NTf}_{2}\right]$ and $\left[\mathrm{C}_{4} \mathrm{~m}_{2}\right.$ im] $\left[\mathrm{NTf}_{2}\right]$ allow to reach a much deeper moisture elimination, in both cases at the $\mathrm{H}_{2} \mathrm{O}$ detection limit of our Karl-Fischer titration $\leq 4 \mathrm{ppm}$ (entries 4 and 5). The same B treatment was applied by O'Mahony et al. [29] to $\left[\mathrm{C}_{4} \mathrm{mim}\right]\left[\mathrm{BF}_{4}\right],\left[\mathrm{C}_{4} \mathrm{mim}\right]\left[\mathrm{NTf}_{2}\right],\left[\mathrm{C}_{4} \mathrm{~m}_{2} \mathrm{im}\right]\left[\mathrm{NTf}_{2}\right]$ at $50^{\circ} \mathrm{C}$ obtaining water contents of 119,144 and 295 ppm, respectively. These values are clearly higher than those here reported, especially when $\mathrm{NTf}_{2}$ anion is present in the RTIL, which may be caused by the cooling step between the purification and the analysis or because those RTILs were initially too wet to be dried in only 24h. Table 1 also shows how treatment ( $C$, entry 6 ) provides comparable results to treatment ( $B$, entry 4 ) in terms of water removal. However, it is worth noting that the use of molecular sieves (zeolites with a defined pore size) in treatment (C) may also remove other minor impurities present in RTILs different than water as will be shown and discussed afterwards. Sweeny et al. [28] and Gnahm et al. [30] also used a similar purification method. They removed the voltammetric features associated to the presence of impurities by adding molecular sieves to the electrochemical cell under stirring. Unfortunately, they do not mention RTILs water content within the electrochemical cell, and a direct comparison with our results is not possible. In this sense, we have also noticed that if the molecular sieve-containing RTIL is stirred, this acquires a certain turbidity and, therefore, we have decided not stirring during the molecular sieve treatment.

Bubbling $\mathrm{Ar}$, or other inert gas, through the electrolyte is a standard protocol in electrochemistry in order to remove $\mathrm{O}_{2}$ dissolved. However, in the case of RTILs, may result inconvenient. In fact, after $30 \mathrm{~min}$ of $\mathrm{Ar}$ bubbling in $\left[\mathrm{C}_{4} \mathrm{mim}\right]\left[\mathrm{BF}_{4}\right]$, the $\mathrm{H}_{2} \mathrm{O}$ content very significantly increases from 30 to $580 \mathrm{ppm}$ (entry 1, Table 2), which totally throws away any improvement reached during the RTIL purification treatment. Similar results were also observed in $\left[\mathrm{C}_{4} \mathrm{mim}\right]\left[\mathrm{NTf}_{2}\right]$ and $\left[\mathrm{C}_{4} \mathrm{~m}_{2} \mathrm{im}\right]\left[\mathrm{NTf}_{2}\right]$ (data not shown). It is well-known that this uncontrolled increase in the water content not only modifies viscosity and narrows the electrochemical window, but also, dramatically affects the electrochemical response if the reaction under study is water-dependent or if water molecules are 
involved in the mechanism. To overcome this source of water income, we have incorporated a gas stream purification filter before the gas reaches the RTIL within the electrochemical cell. As shown in Table 2, the use of that gas filter warranties a constant and reproducible water content in all three imidazolium based RTILs studied. It is also worth noting that when a non-purified RTIL, for instance $\left[\mathrm{C}_{4} \mathrm{mim}\right]\left[\mathrm{BF}_{4}\right]$, is directly bubbled with filtered $\operatorname{Ar}$ (entry 2 in Table 2 ), the water content significantly diminishes from 200 ppm to similar values to those obtained by RTIL purification treatment B (entry 3 , table 2). This points out that a well-dried gas stream can effectively remove most of the water of the RTIL in a short period of time. Thus, for $\left[\mathrm{C}_{4} \mathrm{mim}\right]\left[\mathrm{BF}_{4}\right]$, almost the same value of water is obtained after only 30 min of filtered Ar bubbling versus the $24 \mathrm{~h}$ of treatment B (see Table 2). In the case of more hydrophobic and less viscous RTILs such as $\left[\mathrm{C}_{4} \mathrm{mim}\right]\left[\mathrm{NTf}_{2}\right]$ and $\left[\mathrm{C}_{4} \mathrm{~m}_{2} \mathrm{im}\right]\left[\mathrm{NTf}_{2}\right]$, water content was only kept near the detection limit range when the gas filter was used (entries 4 and 5 in Table 2, respectively). A higher purity Ar gas was also tested for purging RTILs. But even under those high purity gas conditions, the filter is compulsory to keep water at low and constant values.

According to the supplier specifications, the commercially available gas filter used here is mainly composed by activated alumina, activated carbon and other metal oxides like copper, nickel or manganese. Each compound in the filter plays a different role and, for instance, the main responsible of drying the gas stream is the activated alumina, which is way more effective than regular molecular sieves (zeolites) of 3 or $4 \AA$ in pore size. Despite that, if the only purpose is to dry out a gas stream, regular molecular sieves can be effectively used. In addition, these have the advantage of an easy regeneration through thermal treatment. However, for some gases such as $\mathrm{CO}_{2}, 4 \AA$ molecular sieves cannot be used because these also adsorb $\mathrm{CO}_{2}$ and, consequently, $\mathrm{CO}_{2}$ would be trapped within the zeolite porosity and their drying properties will be significantly reduced in a very short period of time.

Figure 1 illustrates the importance of controlling water content for electrocatalytic experiments in imidazolium based RTILs. In particular, Figure 1 reports the voltammetric response of a polycrystalline Pt electrode (Fig $1 \mathrm{~A}$ ) and Pt nanoparticles (Fig 1B) in Ar saturated [ $\left.\mathrm{C}_{4} \mathrm{mim}\right]\left[\mathrm{BF}_{4}\right]$ when different RTIL purification treatments and gas streams are used. According to the data shown in Tables 1 and 2, three main situations can be described; $(i)$ purification treatment $B$ and Ar gas directly bubbled within the electrochemical cell to purge the $\mathrm{O}_{2}$ (red plots), (ii) untreated RTIL and Ar gas bubbled only after filtration (blue plots) and (iii) purification treatment B and Ar gas bubbled only after filtration (black plots). The results shown in figure 1A clearly demonstrate that only if RTIL purification treatment is performed and the Ar gas stream is filtered the corresponding voltammogram is electrochemically featureless (black plot). In contrast, if $\mathrm{Ar}$ gas is directly bubbled without being filtered, the corresponding voltammogram (red plot) shows an irreversible cathodic wave at $-1.2 \mathrm{~V}$ and high currents at both cathodic and anodic limits. These new voltammetric features can be assigned to the increased presence of $\mathrm{H}_{2} \mathrm{O}$ described in Table 2 (from $43 \mathrm{ppm}$ (black plot) to $580 \mathrm{ppm}$ (red plot)), via direct reduction/oxidation or mediating other electrochemical processes. On the other hand, when purification treatment $B$ is not applied before the electrochemical experiment, even though the $\mathrm{Ar}$ gas stream is filtered, two irreversible signals at about -1.2 and $-0.6 \mathrm{~V}$ are observed (blue plot), which are absence if treatment $B$ is carried out. This finding points out the importance of performing treatment B (stirring under vacuum at room temperature for $24 \mathrm{~h}$ ) to remove some volatile electroactive impurities. Interestingly, both cathodic and anodic potential limits are nearly identical when comparing black and blue plots in Fig 1A, which exhibit similar water content, 43 ppm (entry 3, Table 2) and 40 ppm (entry 2, Table 2), respectively. This is not always a common feature in experiments done using RTILs in different days and clearly indicates that if experimental conditions (mainly water content and 
temperature) are well-controlled, reproducible experiments can be performed. Similar findings are observed when Pt nanoparticles are used (Figure 1B). In this case, an additional curve is included (green plot), which corresponds to the response of the bare GC electrode.

Figures $1 \mathrm{~A}$ and $1 \mathrm{~B}$ demonstrate the important correlation between electrochemical response in voltammetry and the existence of RTIL purification treatments and a filtered gas stream for the case of an inert gas (Ar). But it would be even more relevant to discern that type of correlation when a reactive gas such $\mathrm{CO}_{2}$, which concentrates a lot of attention for electroreduction in RTILs [14-17, 22$24,40]$, is evaluated. For this reason, Figure $1 \mathrm{C}$ displays the voltammetric results obtained comparing the effect of purging $\left[\mathrm{C}_{4} \mathrm{mim}\right]\left[\mathrm{BF}_{4}\right]$ with filtered and unfiltered $\mathrm{CO}_{2}$ gas streams (entries 7 and 6 in table 2 , respectively). For sake of comparison, the response obtained when $\left[\mathrm{C}_{4} \mathrm{mim}\right]\left[\mathrm{BF}_{4}\right]$ is pretreated using purification treatment $B$ and purged with filtered Ar gas stream (final water content $50 \mathrm{ppm}$ ) is also included in Figure $1 \mathrm{C}$ (black plot). Subsequently, $\mathrm{CO}_{2}$ is bubbled filtered (blue plot) and unfiltered (red plot). Thus, when the $\mathrm{CO}_{2}$ is passed through the gas filter (blue plot, Figure $1 \mathrm{C}$ ), the RTIL water content remains stable (aprox. 50-60 ppm) and the voltammetric response is basically identical to the one obtained when filtered $\mathrm{Ar}$ is used (black plot, Figure $1 \mathrm{C}$ ). This finding points out that, under these conditions, the $\mathrm{CO}_{2}$ electroreduction does not take place, that is, $\mathrm{Pt}$ nanoparticles are inactive towards $\mathrm{CO}_{2}$ electroreduction in pure $\left[\mathrm{C}_{4} \mathrm{mim}\right]\left[\mathrm{BF}_{4}\right]$. However, if the $\mathrm{CO}_{2}$ gas is bubbled without the gas filter (red plot, Figure $1 \mathrm{C}$ ), the voltammetric response displays, in the cathodic potential region, a clear reduction process with an onset potential at $-0.9 \mathrm{~V}$, as well as, in the positive going-sweep, a wide oxidation process centred at $-0.71 \mathrm{~V}$. Obviously, these new features should not be related to the $\mathrm{CO}_{2}$ electrochemical reduction on Pt nanoparticles in $\left[\mathrm{C}_{4} \mathrm{mim}\right]\left[\mathrm{BF}_{4}\right]$, since the RTIL water content has been hardly modified. Actually, Karl-Fischer analyses (see Table 2, entry 6) clearly indicate that the water content significantly increases from $50 \mathrm{ppm}$ to $3100 \mathrm{ppm}$ due to the inappropriate use of an unfiltered $\mathrm{CO}_{2}$ gas stream.

The high $\mathrm{H}_{2} \mathrm{O}$ uptake capacity of $\left[\mathrm{C}_{4} \mathrm{mim}\right]\left[\mathrm{BF}_{4}\right]$ from gas stream when gas filter is not used, could be related to its hydrophilicity. In fact, this RTIL is completely miscible with water and it is also able to absorb large quantities of $\mathrm{H}_{2} \mathrm{O}$ from the atmosphere [29]. On the contrary, [ $\left.\mathrm{C}_{4} \mathrm{mim}\right]\left[\mathrm{NTf}_{2}\right]$ and $\left[\mathrm{C}_{4} \mathrm{~m}_{2} \mathrm{im}\right]\left[\mathrm{NTf}_{2}\right]$ are not miscible with water and have less capacity of absorb $\mathrm{H}_{2} \mathrm{O}$ from the atmosphere. In this way, in order to correlate the capacity of water absorption from a gas stream and the hydrophilic or hydrophobic character of a RTIL, equivalent experiments to the ones performed in $\left[\mathrm{C}_{4} \mathrm{mim}\right]\left[\mathrm{BF}_{4}\right]$ were also done in $\left[\mathrm{C}_{4} \mathrm{mim}\right]\left[\mathrm{NTf}_{2}\right]$ and $\left[\mathrm{C}_{4} \mathrm{~m}_{2}\right.$ im] $\left[\mathrm{NTf}_{2}\right]$. It is also worth noting that these two RTILs are also widely used for $\mathrm{CO}_{2}$ electro-reduction in numerous contributions $[40,41]$.

Figure 2A (red plot) shows the voltammetric response of a polycrystalline Pt electrode in $\left[\mathrm{C}_{4}\right.$ mim] $\left[\mathrm{NTf}_{2}\right]$ after purification treatment $\mathrm{B}$ and using a filtered $\mathrm{Ar}$ gas stream. Despite a very low water content (see Tables 1 and 2), a pseudo reversible electrochemical signal at -1.37 and $-1.05 \mathrm{~V}$ is clearly observed indicating the presence of electroactive impurities that cannot be removed using the treatment B. However, if the molecular sieves based treatment $(C)$ is performed (see experimental section for details), similar low water contents (entry 4, Table 2) are obtained and the corresponding voltammogram (black plot) do not show the presence of electroactive impurities and a well-defined featureless electrochemical response is reached. This electroactive impurity is probably a cation coming from the synthesis process of the $\left[\mathrm{C}_{4} \mathrm{mim}\right]\left[\mathrm{NTf}_{2}\right]$, which could be effectively trapped in the small pores of the molecular sieve (these are composed by zeolites and can exchange cations with the media). 
After being able to obtain a featureless voltammetric response in $\left[\mathrm{C}_{4} \mathrm{mim}\right]\left[\mathrm{NTf} \mathrm{f}_{2}\right], \mathrm{CO}_{2}$ electrochemical reduction experiments were also performed as previously done in $\left[\mathrm{C}_{4} \mathrm{mim}\right]\left[\mathrm{BF}_{4}\right]$. The results obtained using Pt nanoparticles are shown in figure 2B. Again, for sake of comparison, the response after purification treatment $C$ and filtered $\mathrm{Ar}$ gas stream (water content below $4 \mathrm{ppm}$ ) is also included (black plot). As previously observed in $\left[\mathrm{C}_{4} \mathrm{mim}\right]\left[\mathrm{BF}_{4}\right]$, the electrochemical response seems to be strongly dependent on the RTIL water content. Thus, when the $\mathrm{CO}_{2}$ is directly bubbled without being filtered, the water content remarkably increases from less than 4 ppm (black plot, Figure 2B) to 623 $\mathrm{ppm}$ (red plot, Figure 2B). At this respect, it is worth mentioning that the water content in [ $\left.\mathrm{C}_{4} \mathrm{mim}\right]\left[\mathrm{NTf}_{2}\right]$, for similar $\mathrm{CO}_{2}$ bubbling condition (time and flux), is about 5 times lower than that obtained in [ $\left.\mathrm{C}_{4} \mathrm{mim}\right]\left[\mathrm{BF}_{4}\right]$ (623 vs $3100 \mathrm{ppm}$, respectively). This indicates that a hydrophobic RTIL has a lower tendency to absorb water from the gas stream. Under these conditions, the electrochemical response in $\mathrm{Ar}$ and $\mathrm{CO}_{2}$ purged $\left[\mathrm{C}_{4} \mathrm{mim}\right]\left[\mathrm{NTf}_{2}\right]$ is clearly different and the voltammogram in the presence of $\mathrm{CO}_{2}$ and higher water concentration show a current increase in the reduction region, with an onset potential at about $-1.1 \mathrm{~V}$ and an anodic contribution centered at $-0.75 \mathrm{~V}$. However, if the $\mathrm{CO}_{2}$ gas stream is filtered (blue plot, Figure 2B) and despite the water content remains very low (less than $4 \mathrm{ppm}$ ), the voltammetric response, in comparison with the one without $\mathrm{CO}_{2}$ (black plot), also shows some particular features (a current increase in the reduction region, with a potential onset of $-1.1 \mathrm{~V}$ and an anodic peak at $-0.6 \mathrm{~V}$ ), which can be related to a certain $\mathrm{CO}_{2}$ reduction activity. This situation seems to be different to the case of $\left[\mathrm{C}_{4} \mathrm{mim}\right]\left[\mathrm{BF}_{4}\right]$, where, for equivalent water contents, the voltammogram in presence of $\mathrm{CO}_{2}$ is essentially similar to that without $\mathrm{CO}_{2}$ (Ar saturated).

To complete this study, a similar analysis was also done in $\left[\mathrm{C}_{4} \mathrm{~m}_{2} \mathrm{im}\right]\left[\mathrm{NTf}_{2}\right]$, which has the position 2 of the imidazolium ring blocked by a methyl group. This position has been extensively studied for its implications in the formation of hydrogen bonds with species like $\mathrm{H}_{2} \mathrm{O}$ [42]. Moreover, it was reported that $\mathrm{CO}_{2}$ can form an adduct with the imidazolium ring in this $\mathrm{C2}$-position [14-15, 22, $41,43]$, which stabilizes the $\mathrm{CO}_{2}$ anion radical intermediate. However, there is some controversy at this point, since it was also claimed that the $\mathrm{C} 4$ - and $\mathrm{C} 5$-protons on the imidazolium ring are relevant positions for $\mathrm{CO}_{2}$ catalytic reduction [24].

The behavior of a polycrystalline Pt electrode in $\left[\mathrm{C}_{4} \mathrm{~m}_{2} \mathrm{im}\right]\left[\mathrm{NTf}_{2}\right]$ is shown in Figure $3 \mathrm{~A}$. As previously discussed in the case of $\left[\mathrm{C}_{4} \mathrm{mim}\right]\left[\mathrm{NTf}_{2}\right]$, purification treatment $B$ is not effective enough against some electroactive impurities. For this reason, red plot in Figure $3 \mathrm{~A}$ clearly shows the presence of an electroactive impurity. In contrast, purification treatment $C$ is able to mostly remove this impurity and a featureless electrochemical response is achieved for $\left[\mathrm{C}_{4} \mathrm{~m}_{2} \mathrm{im}\right]\left[\mathrm{NTf}_{2}\right]$ using filter Ar gas stream (black plot, Fig. 3A). In terms of water content (tables 1 and 2), these are very low and similar to those reported for $\left[\mathrm{C}_{4} \mathrm{mim}\right]\left[\mathrm{NTf}_{2}\right]$. Figure $3 \mathrm{~B}$ reports the voltammetric profiles obtained for $\mathrm{CO}_{2}$ electroreduction on Pt nanoparticles. If the $\mathrm{CO}_{2}$ gas stream is not filtered, the water content increases from less than $4 \mathrm{ppm}$ (entry 5, Table 2) to $480 \mathrm{ppm}$ (entry 11, Table 2) (this value is similar to that obtained with $\left[\mathrm{C}_{4} \mathrm{mim}\right]\left[\mathrm{NTf}_{2}\right]$ for similar bubbling conditions). Then, the voltammetric response using unfiltered $\mathrm{CO}_{2}$ gas stream (red plot, $\mathrm{Fig} 3 \mathrm{~B}$ ) shows an evident current increase in the reduction region (onset about -1.2) and an oxidation process centered at about $-0.8 \mathrm{~V}$. Similar features were observed in figure $2 \mathrm{~B}$ for $\left[\mathrm{C}_{4} \mathrm{mim}\right]\left[\mathrm{NTf}_{2}\right]$. In contrast, if the $\mathrm{CO}_{2}$ gas stream is conveniently filtered, the water content remains very low (below $4 \mathrm{ppm}$ ) and the corresponding voltammetric response (blue plot, Fig. 3B), in comparison with that in the absence of $\mathrm{CO}_{2}$ ( $\mathrm{Ar}$ saturated, black plot, Fig. 3B) exhibits some particular features, which can be related to a certain $\mathrm{CO}_{2}$ reduction activity. These findings clearly point out that, under controlled experimental conditions, the behavior of $\left[\mathrm{C}_{4} \mathrm{mim}\right]\left[\mathrm{NTf} f_{2}\right]$ and $\left[\mathrm{C}_{4} \mathrm{~m}_{2} \mathrm{im}\right]\left[\mathrm{NTf} f_{2}\right]$ 
towards $\mathrm{CO}_{2}$ electroreduction on Pt nanoparticles is essentially the same. Thus, suggesting that $\mathrm{C2}$ position on the imidazolium ring is not the key position towards $\mathrm{CO}_{2}$ electrochemical reduction, since in both cases Pt nanoparticles have exhibited $\mathrm{CO} 2$ reduction activity in spite of the fact that $\mathrm{C2}$-position is only available in the case of $\left[\mathrm{C}_{4} \mathrm{mim}\right]\left[\mathrm{NTf}_{2}\right]$.

\section{Conclusions}

The use of RTILs for electrocatalytic studies is a promising field. However, controlling some critical experimental parameters such as water content and temperature is necessary to properly understand the role played by gas reactants such as $\mathrm{CO}_{2}$ in RTILs. In this contribution, we study the effect of different experimental conditions (RTIL purification treatment and RTIL gas stream purge within the electrochemical cell) by cyclic voltammetry for three different imidazolium based RTILs. In particular, 3 different pre-treatments have been performed to purify imidazolium based RTILs. In the case of $\left[\mathrm{C}_{4} \mathrm{mim}\right]\left[\mathrm{BF}_{4}\right]$, the vacuum-stirring treatment in combination with the use of a filtered gas stream within the electrochemical cell allow to reach a features voltammogram. In contrast, in the cases of $\left[\mathrm{C}_{4} \mathrm{mim}\right]\left[\mathrm{NTf}_{2}\right]$ and $\left[\mathrm{C}_{4} \mathrm{~m}_{2} \mathrm{im}\right]\left[\mathrm{NTf}_{2}\right]$, the presence of some electroactive impurities was only removed using the molecular sieves based treatment in combination with a filtered gas stream within the electrochemical cell. Moreover, we have clearly demonstrated that controlling the water content is a critical parameter for evaluating electrocatalytic activity for $\mathrm{CO}_{2}$ electroreduction reaction. This water content (measured by Karl-Fisher titration) must be controlled not only before, but also during the electrochemical test. In this regard, the use of a convenient gas filter has been demonstrated to be of outstanding importance for both, inert or reactive gases ( $\mathrm{Ar}$ and $\mathrm{CO}_{2}$, respectively). Thus, under controlled experimental conditions, we have demonstrated that the $\mathrm{CO}_{2}$ electroreduction on $\mathrm{Pt}$ nanoparticles in $\left[\mathrm{C}_{4} \mathrm{mim}\right]\left[\mathrm{BF}_{4}\right]$ is negligible. In contrast, a clear $\mathrm{CO}_{2}$ activity is exhibited in $\left[\mathrm{C}_{4} \mathrm{mim}\right]\left[\mathrm{NTf} \mathrm{f}_{2}\right]$ and $\left[\mathrm{C}_{4} \mathrm{~m}_{2} \mathrm{im}\right]\left[\mathrm{NTf}_{2}\right]$. A very similar electrocatalytic behavior for $\mathrm{CO}_{2}$ reduction is reported in $\left[\mathrm{C}_{4} \mathrm{mim}\right]\left[\mathrm{NTf}_{2}\right]$ and $\left[\mathrm{C}_{4} \mathrm{~m}_{2} \mathrm{im}\right]\left[\mathrm{NTf}_{2}\right]$, which suggests that $\mathrm{C}-2$ position at the imidazolium ring is not the key position in $\mathrm{CO}_{2}$ electrochemical reduction on Pt nanoparticles.

\section{Conflicts of interest}

There are no conflicts to declare.

\section{Acknowledgements}

The authors acknowledge financial support from the Spanish Ministry of Economy and Competitiveness (MINECO) (projects CTQ2013-48280-C3-3-R and CTQ2016-76231-C2-2-R) (AEI/FEDER, UE) and from the CNRS (projet Défi Instrumentation aux limites 2015). J.S-G. acknowledges financial support from VITC (Vicerrectorado de Investigación y Transferencia de Conocimiento) of the University of Alicante (UATALENTO16-02). C.M.S-S. acknowledges financial support from the University of Alicante, visiting researcher grant INV16-15. 


\section{Notes and references}

1 J.S. Wilkes, Green Chem., 2002, 4, 73-80.

2 X. Wang, Z. You, Y. Cheng, H. Sha, G. Li, H. Zhu, W. Sun, J. Mol. Liq., 2015, 204, 112-117.

3 E.S. Forzani, D. Lu, M.J. Leright, A. Diaz Aguilar, F. Tsow, R.A. Iglesias, Q. Zhang, J. Lu, J. Li, N. Tao, J. Am. Chem. Soc., 2009, 131, 1390-1391.

4 M. Kathiresan, D. Velayutham, Chem. Commun., 2015, 51, 17499-17516.

5 X. Lu, J. Zhou, Y. Zhao, Y. Qiu, J. Li, Chem. Mater., 2008, 20, 3420-3424.

6 Z. Li, H. Liu, Y. Liu, P. He, J. Li, J. Phys. Chem. B, 2004, 108, 17512-17518.

7 Y. Zhang, Y. Shen, J. Yuan, D. Han, Z. Wang, Q. Zhang, L. Niu, Angew. Chem. Int. Ed., 2006, 45, 5867-5870.

8 F. He, X. Chen, Y. Shen, Y. Li, A. Liu, S. Liu, T. Mori, Y. Zhang, J. Mater. Chem. A, 2016, 4, 6630-6638.

9 M.H. Chakrabarti, F.S. Mjalli, I.M. AlNashef, M.A. Hashim, M.A. Hussain, L. Bahadori, C.T.J. Low, Renew. Sust. Energ. Rev., 2014, 30, 254-270.

10 A.J.R. Rennie, N. Sanchez-Ramirez, R.M. Torresi, P.J. Hall, J. Phys. Chem. Lett., 2013, 4, $2970-2974$.

11 C. Pozo-Gonzalo, L.R. Johnson, E. Jonsson, C. Holc, R. Kerr, D.R. MacFarlane, P.G. Bruce, P.C. Howlett, M. Forsyth, J. Phys. Chem. C, 2017, 121, 23307-23316.

12 A. Ejigu, L. Johnson, P. Licence, D.A. Walsh., Electrochem. Commun., 2012, 23, 122-124.

13 F.A. Hanc-Scherer, C.M. Sánchez-Sánchez, P. Ilea, E. Herrero, ACS Catal., 2013, 3, 2935-2938.

14 C.M. Sanchez-Sanchez, in: K. Wandelt (Ed.), Encyclopedia of Interfacial Chemistry: Surface Science and Electrochemistry, Elsevier, 2018. https://doi.org/10.1016/B978-0-12-409547-2.13377-3

15 F.A. Hanc-Scherer, M.A. Montiel, V. Montiel, E. Herrero, C.M. Sánchez-Sánchez, Phys. Chem. Chem. Phys., 2015, 17, 23909-23916.

16 B. Kumar, M. Asadi, D. Pisasale, S. Sinha-Ray, B.A. Rosen, R. Haasch, J.A. Abiade, A.L. Yarin, A. Salehi-Khojin, Nat. Commun., 2013, 4, 2819-2826.

17 M. Alvarez-Guerra, J. Albo, E. Alvarez-Guerra, A., Energy Environ. Sci., 2015, 8, 2574-2599.

18 Q. Zhu, J. Ma, X. Kang, X. Sun, H. Liu, J. Hu, Z. Liu, B. Han, Angew. Chem. Int. Ed., 2016, 55, 9012-9016.

19 F. Endres, S.Z. El Abedin, Phys. Chem. Chem. Phys., 2006, 8, 2101-2116.

20 M. Galinski, A. Lewandowski, I. Stepniak, Electrochim. Acta, 2006, 51, 5567-5580.

21 H. Liu, Y. Liu, J. Li, Phys. Chem. Chem. Phys., 2010, 12, 1685-1697.

22 B.A. Rosen, A. Salehi-Khojin, M.R. Thorson, W. Zhu, D.T. Whipple, P.J.A. Kenis, R.I. Masel, Science, 2011, 334, 643644.

23 Y. Matsubara, D.C. Grills, Y. Kuwahara, ACS Catal., 2015, 5, 6440-6452.

24 G.P.S. Lau, M. Schreier, D. Vasilyev, R. Scopelliti, M. Grätzel, P.J. Dyson, J. Am. Chem. Soc., 2016, $138,7820-7823$.

25 J. Solla-Gullón, F.J. Vidal-Iglesias, A. López-Cudero, E.Garnier, J. M. Feliu, A. Aldaz, , Phys. Chem. Chem. Phys., 2008, 10, 3689-3698.

26 J.V.Perales-Rondón, E. Herrero, J. Solla-Gullón, C.M. Sánchez-Sánchez, V. Vivier, J. Electroanal. Chem. 2017, 793, 218-225.

27 C.M. Sánchez-Sánchez, J. Solla-Gullón, F.J. Vidal-Iglesias, A. Aldaz, V. Montiel, E. Herrero, J. Am. Chem. Soc., 2010, 132, 5622-5624.

28 B.K. Sweeny, D.G. Peters, Electrochem. Commun., 2001, 3, 712-715.

29 A.M. O'Mahony, D.S. Silvester, L. Aldous, C. Hardacre, R.G. Compton, J. Chem. Eng. Data, 2008, 53, 2884-2891.

30 M. Gnahm, D.M. Kolb, J. Electroanal. Chem., 2011, 651, 250-252.

31 M.A. Montiel, J. Solla-Gullón, C.M. Sánchez-Sánchez, J. Solid. State. Electrochem., 2016, 20, 1043-1052.

32 Y. Shen, Y. Zhang, D. Han, Z. Wang, D. Kuehner, L. Niu, Talanta, 2009, 78, 805-808.

33 J.T. Frith, A. E. Russel, N. Garcia-Araez, J.R. Owen, Electrochem. Commun., 2014, 46, 33-35.

34 A. Lewandowski, L. Waligora. M. Galinski, Electroanal., 2009, 21, 2221-2227.

35 Z. Liu, S.Z. El Abedin, N. Borisenko, F. Endres, Chemelectrochem, 2015, 2, 1159-1163.

36 M. Kar, Z. Ma, L.M. Azofra, K., Chem. Commun., 2016, 52, 4033-4036.

37 S.S. Moganty, R.E. Baltus, D. Roy, Chem. Phys. Lett., 2009, 483, 90-94.

38 I.M. Al Nashef, M.L. Leonard, M.C. Kittle, M.A. Matthews, J.W. Weidner, Electrochem. Solid-State. Lett., 2001, 4 11, D16-D18.

39 A.A. Isse, L. Scarpa, C. Durante, A. Gennaro, Phys. Chem. Chem. Phys., 2015, 17, 31228-31236.

40 E.L. Tanner, C. Batchelor-McAuley and R.G. Compton, J. Phys. Chem. C, 2016, 120, 26442-26447.

41 R. Michez, T. Doneux, C. Buess-Herman and M. Luhmer, ChemPhysChem, 2017, 18, $2208-2216$.

42 K. Dong and S. Zhang, Chem. Eur. J., 2012, 18, 2748-2761.

43 R. Michez, J. Vander Steen, T. Doneux, T. Luhmer, C. Buess-Herman, Electrochim. Acta, 2018, $270,434-439$. 
Table 1. $\mathrm{H}_{2} \mathrm{O}$ content quantification in RTILs by Karl-Fischer titration before and after applying different RTIL purification treatments outside the electrochemical cell to $4 \mathrm{~mL}$ samples.

\begin{tabular}{cccccccc}
\hline RTIL & Initial $\left[\mathrm{H}_{2} \mathrm{O}\right] / \mathrm{ppm}$ & Vacuum Time $/ \mathrm{h}$ & $\begin{array}{c}\text { 1olecular } \\
\text { ve time } / \mathrm{h}\end{array}$ & $\mathrm{T} /{ }^{\circ} \mathrm{C}$ & Il $\left[\mathrm{H}_{2} \mathrm{O}\right] / \mathrm{ppm}$ reatments & Entry \\
\hline$\left[\mathrm{C}_{4}\right.$ mim $]\left[\mathrm{BF}_{4}\right]$ & 200 & 24 & - & 80 & 62 & $\mathrm{~A}$ \\
\hline$\left[\mathrm{C}_{4}\right.$ mim $]\left[\mathrm{BF}_{4}\right]$ & 200 & 24 & - & R.T. & 32 & $\mathrm{~B}$ \\
{$\left[\mathrm{C}_{4}\right.$ mim $]\left[\mathrm{BF}_{4}\right]$} & 413 & 24 & - & R.T. & 41 & $\mathrm{~B}$ & 3 \\
{$\left[\mathrm{C}_{4}\right.$ mim $]\left[\mathrm{NTf}_{2}\right]$} & 200 & 24 & - & R.T. & $\leq 4$ & $\mathrm{~B}$ & 4 \\
{$\left[\mathrm{C}_{4} \mathrm{~m}_{2} \mathrm{im}\right]\left[\mathrm{NTf}_{2}\right]$} & 732 & 24 & - & R.T. & $\leq 4$ & $\mathrm{~B}$ & 5 \\
\hline$\left[\mathrm{C}_{4}\right.$ mim $]\left[\mathrm{NTf}_{2}\right]$ & 200 & 6 & - & R.T. & $\leq 4$ & $\mathrm{C}$ & 6
\end{tabular}


Table 2. $\mathrm{H}_{2} \mathrm{O}$ content quantification in RTILs by Karl-Fischer titration before and after applying different RTIL purification treatments outside the electrochemical cell to $4 \mathrm{~mL}$ samples and after purging them with either $\operatorname{Ar}$ or $\mathrm{CO}_{2}$ gas streams within the electrochemical cell.

\begin{tabular}{|c|c|c|c|c|c|c|c|c|}
\hline RTIL & $\begin{array}{c}\text { Initial } \underset{2}{\left[\mathrm{H}_{2} \mathrm{O}\right]} \\
/ \mathrm{ppm}\end{array}$ & $\begin{array}{c}\text { Purification } \\
\text { treatment }\end{array}$ & $\begin{array}{c}{\left[\mathrm{H}_{2} \mathrm{O}\right] \text { after }} \\
\text { purification / } \\
\text { ppm }\end{array}$ & $\begin{array}{c}\text { Bubbling } \\
\text { time/ min }\end{array}$ & Gas & Gas filter & $\begin{array}{c}{\left[\mathrm{H}_{2} \mathrm{O}\right] \text { after gas }} \\
\text { purge /ppm }\end{array}$ & Entry \\
\hline$\left[\mathrm{C}_{4} \mathrm{mim}\right]\left[\mathrm{BF}_{4}\right]$ & 200 & B & 30 & 30 & $\mathrm{Ar}$ & No & 580 & 1 \\
\hline$\left[\mathrm{C}_{4} \mathrm{mim}\right]\left[\mathrm{BF}_{4}\right]$ & 200 & - & 200 & 30 & $\mathrm{Ar}$ & Yes & 40 & 2 \\
\hline$\left[\mathrm{C}_{4} \mathrm{mim}\right]\left[\mathrm{BF}_{4}\right]$ & 210 & B & 40 & 30 & $\mathrm{Ar}$ & Yes & 43 & 3 \\
\hline$\left[\mathrm{C}_{4} \mathrm{mim}\right]\left[\mathrm{NTf}_{2}\right]$ & 200 & C & $\leq 4$ & 30 & $\operatorname{Ar}$ & Yes & 16 & 4 \\
\hline$\left[\mathrm{C}_{4} \mathrm{~m}_{2} \mathrm{im}\right]\left[\mathrm{NTf}_{2}\right]$ & 740 & C & $\leq 4$ & 30 & $\mathrm{Ar}$ & Yes & $\leq 4$ & 5 \\
\hline$\left[\mathrm{C}_{4} \mathrm{mim}\right]\left[\mathrm{BF}_{4}\right]$ & 210 & B & 50 & 30 & $\mathrm{CO}_{2}$ & No & 3100 & 6 \\
\hline$\left[\mathrm{C}_{4} \mathrm{mim}\right]\left[\mathrm{BF}_{4}\right]$ & 210 & B & 50 & 30 & $\mathrm{CO}_{2}$ & Yes & 60 & 7 \\
\hline$\left[\mathrm{C}_{4} \mathrm{mim}\right]\left[\mathrm{NTf}_{2}\right]$ & 190 & C & $\leq 4$ & 30 & $\mathrm{CO}_{2}$ & Yes & $\leq 4$ & 8 \\
\hline$\left[\mathrm{C}_{4} \mathrm{mim}\right]\left[\mathrm{NTf}_{2}\right]$ & 190 & C & $\leq 4$ & 30 & $\mathrm{CO}_{2}$ & No & 623 & 9 \\
\hline$\left[\mathrm{C}_{4} \mathrm{~m}_{2} \mathrm{im}\right]\left[\mathrm{NTf}_{2}\right]$ & 740 & C & $\leq 4$ & 30 & $\mathrm{CO}_{2}$ & Yes & $\leq 4$ & 10 \\
\hline$\left[\mathrm{C}_{4} \mathrm{~m}_{2} \mathrm{im}\right]\left[\mathrm{NTf}_{2}\right]$ & 740 & C & $\leq 4$ & 30 & $\mathrm{CO}_{2}$ & No & 480 & 11 \\
\hline
\end{tabular}


Figure 1. Cyclic voltammograms in $\left[\mathrm{C}_{4} \mathrm{mim}\right]\left[\mathrm{BF}_{4}\right]$ after following different experimental procedures. (A) Polycrystalline Pt electrode and (B and C) Pt nanoparticles. In figures $1 \mathrm{~A}$ and $1 \mathrm{~B}$, (red plots) correspond to purification treatment $B$ and Ar gas stream without being filtered, (blue plots) correspond to untreated RTIL and filtered Ar gas stream and (black curves) correspond to purification treatment B and filtered Ar gas stream. Green plot in Figure $1 \mathrm{~B}$ corresponds to the bare GC electrode response. Water concentration in Figure $1 B$ plots is 76, 70, 580 and 72 ppm for black, blue, red and green plots, respectively. In figure 1C, (red plot) corresponds to purification treatment $\mathrm{B}$ and $\mathrm{CO}_{2}$ gas stream without being filtered, (blue plot) corresponds to purification treatment $\mathrm{B}$ and filtered $\mathrm{CO}_{2}$ gas stream and (black plot) corresponds to purification treatment $\mathrm{B}$ and filtered Ar gas stream. Scan rate in all cases $50 \mathrm{mV} / \mathrm{s}$.

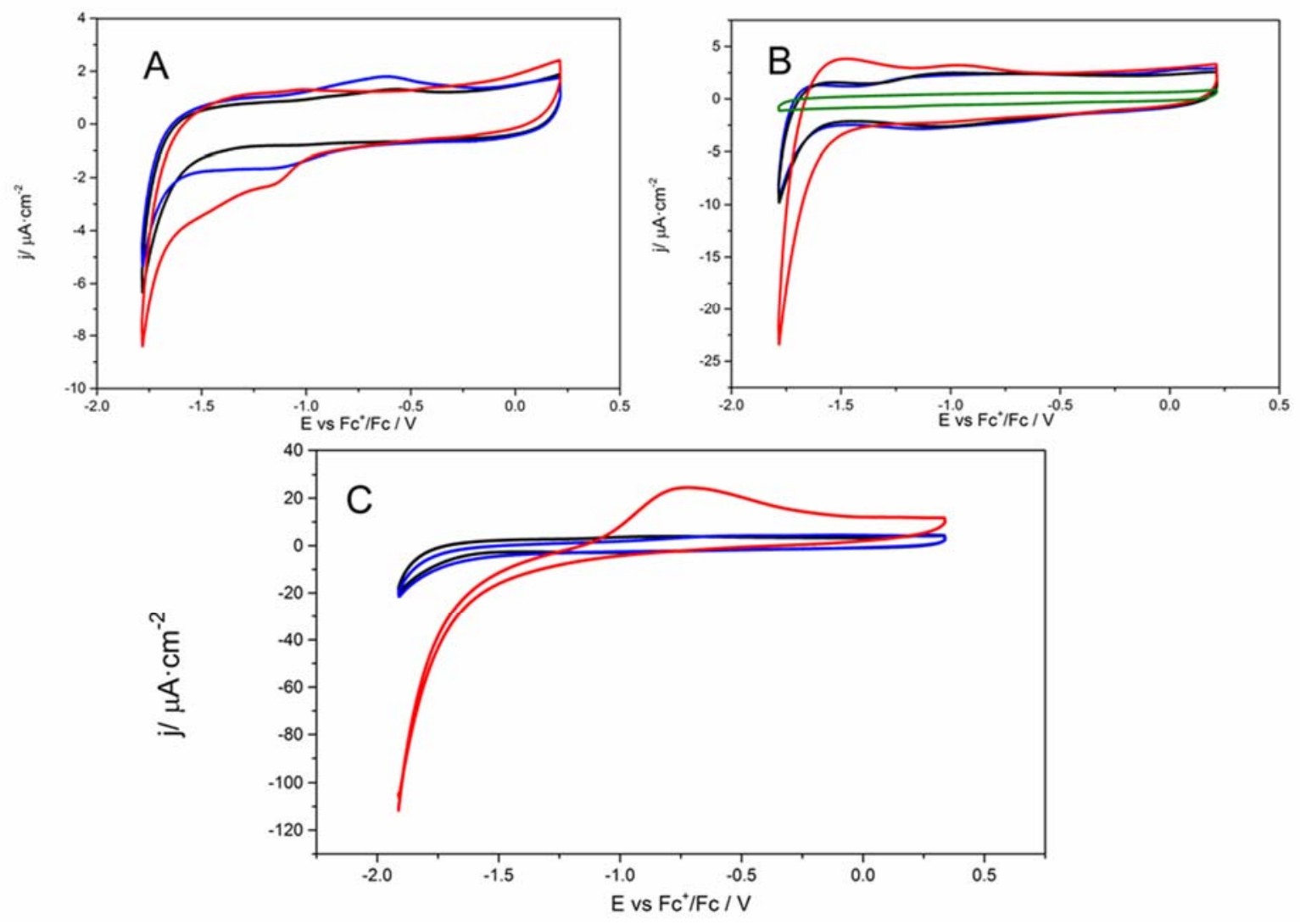


Figure 2. (A) Cyclic voltammograms of a polycrystalline Pt electrode in [C4mim][NTf2]. (Red plot) purification treatment $B$ and filtered $A r$ gas stream and (black plot) purification treatment $C$ and filtered Ar gas stream. (B) Cyclic voltammograms at Pt nanoparticles in [C4mim][NTf2]. (Black plot) purification treatment $C$ and filtered $A r$ gas stream, (blue plot) purification treatment $C$ and filtered $\mathrm{CO} 2$ and (red plot) purification treatment $\mathrm{C}$ and unfiltered $\mathrm{CO} 2$ gas stream. Scan rate in all cases $50 \mathrm{mV} / \mathrm{s}$.
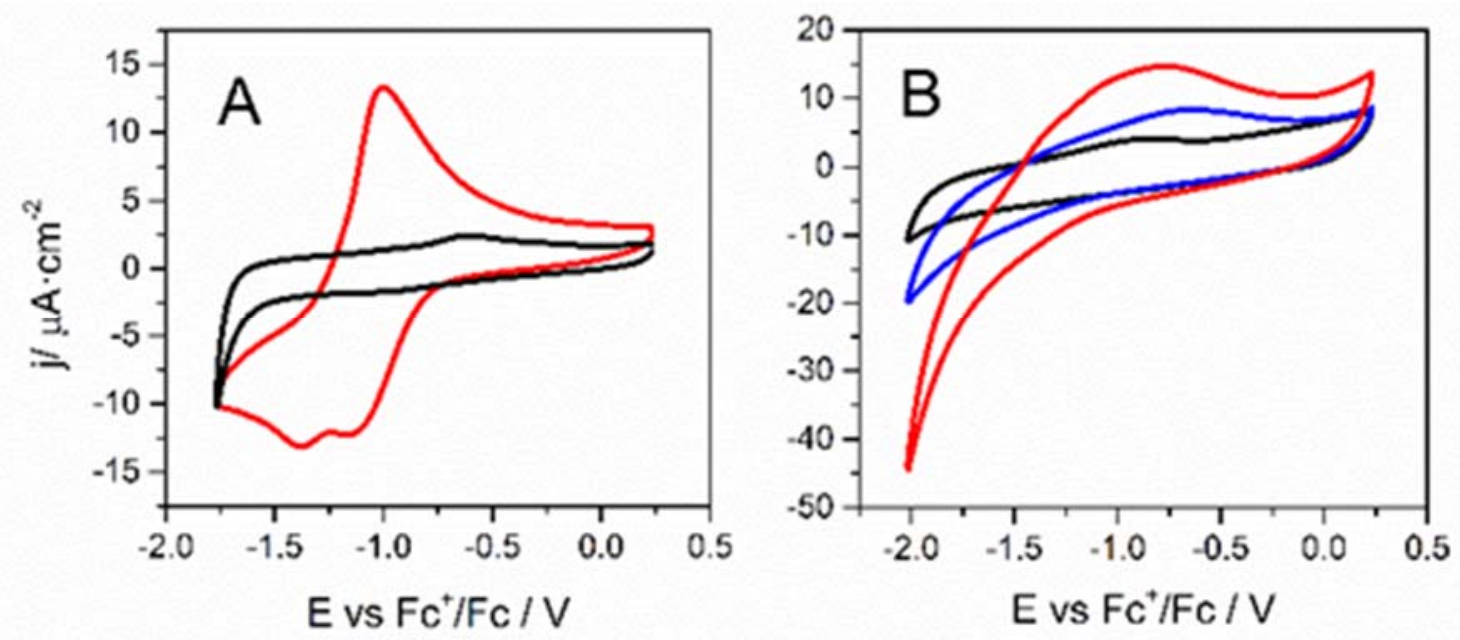
Figure 3. (A) Cyclic voltammograms of a polycrystalline Pt electrode in $\left[\mathrm{C}_{4} \mathrm{~m}_{2}\right.$ im] $\left[\mathrm{NTf}_{2}\right]$. (Red plot) purification treatment $B$ and filtered $A r$ gas stream and (black plot) purification treatment $C$ and filtered Ar gas stream. (B) Cyclic voltammograms at Pt nanoparticles in $\left[\mathrm{C}_{4} \mathrm{~m}_{2} \mathrm{im}\right]\left[\mathrm{NTf}_{2}\right]$. (Black plot) purification treatment $C$ and filtered $A r$ gas stream, (blue plot) purification treatment $C$ and filtered $\mathrm{CO}_{2}$ and (red plot) purification treatment $\mathrm{C}$ and unfiltered $\mathrm{CO}_{2}$ gas stream. Scan rate in all cases $50 \mathrm{mV} / \mathrm{s}$.
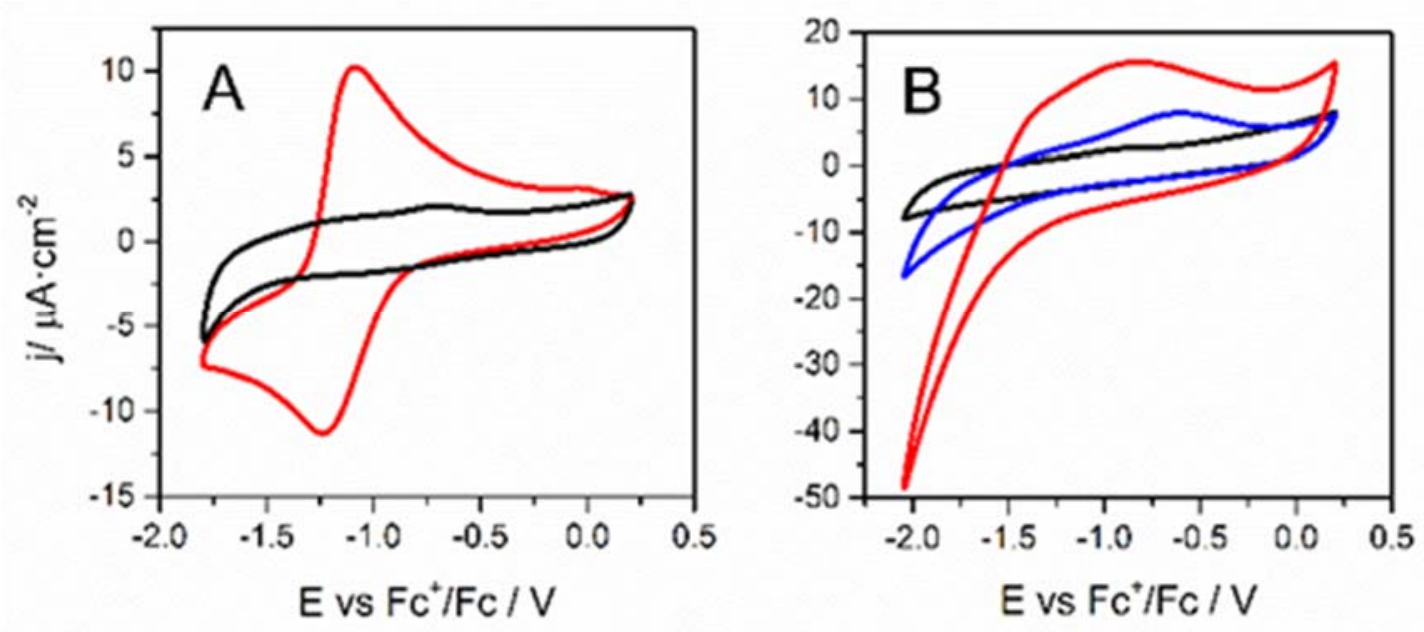